Portland State University

PDXScholar

\title{
The More Things Change: The Collaborative Art Library
}

Elsa Loftis

Portland State University, eloftis@pdx.edu

Follow this and additional works at: https://pdxscholar.library.pdx.edu/ulib_fac

Part of the Collection Development and Management Commons Let us know how access to this document benefits you.

\section{Citation Details}

Loftis, Elsa, "The More Things Change: The Collaborative Art Library" (2019). Library Faculty Publications and Presentations. 279.

https://pdxscholar.library.pdx.edu/ulib_fac/279

This Post-Print is brought to you for free and open access. It has been accepted for inclusion in Library Faculty Publications and Presentations by an authorized administrator of PDXScholar. Please contact us if we can make this document more accessible: pdxscholar@pdx.edu. 
The More Things Change: The Collaborative Art Library

Elsa Loftis, M.L.I.S

Humanities and Acquisitions Librarian

Portland State University

Shortened title: The More Things Change

Keywords:

Art libraries, assessment, collection, collaboration, library as space, materials 


\begin{abstract}
The academic library's art collection has a history of fluidity and flux. Teaching and learning materials that support visual art education can range from traditional formats like image collections and monographs to the curious, the rare, and sometimes the downright unusual. Art library professionals must plan for the future of the academic library collection with intention and sensitivity to the learning styles of their students while adhering to the environmental realities of their governing institutions.
\end{abstract}

One constant is clear, which is that art students are not content to be mere consumers of information and images; they are creators. It is this creative habit of mind that brings them to the study of art in the first place, and it is what will turn them into the makers of the future art library, if we listen to their voices. Though collections will vary in depth and breadth between institutions, the enduring truth is that libraries will need to listen to student input and build lasting partnerships.

\title{
INTRODUCTION
}

Art libraries and their collections are as diverse as the institutions they serve. One library's continued reliance on its vertical picture file may astound the institution that abandoned theirs years ago. Slide libraries are giving way to zine collections and fablabs, but this is not true everywhere. Artists and librarians can reimagine the art library together. This requires outreach and input from students. Ideally, academic art libraries could create a rubric or an evaluation concept for determining how a collection is serving the library's community of users. Of course, this is not easily achieved, due to the aforementioned variance in collection types across institutions. Libraries can find the way to best serve their communities by using some basic data analysis in concert with direct constructive dialog with students and faculty. This dialog can be generated through focus groups and surveys, outlined here, that are adaptable to a variety of institutions and can be understood by art professionals as well as library staff outside of the art world.

\section{ELEMENTS OF A COLLECTION}

In order to envision what the future holds for library collections, one should first acknowledge the lack of uniformity in contemporary academic art library collections. Even a cursory glance at the landscape of various art library collections in North America will reveal an abundance of diversity. The resources amassed at institutions reflect the budgetary priorities and the curricula of the individual colleges served by the library. 
While it may be difficult to generalize, common elements of an art library collection in an academic context will include monographs relating to art history and artists, exhibition catalogs, core art journal subscriptions, and some access to images regardless of the medium. Visual resources collections were once predominantly available in the form of $35 \mathrm{~mm}$ slides, photograph collections, or a vertical file; which is/was often a cabinet containing magazine clippings in folders arranged by thematic concept. Those image collections are increasingly being digitized and available electronically, however copyright and image ownership often complicates and slows this process. Collections in some institutions will include ephemera collections that can include gallery announcements, postcards, pamphlets, and so on, and many of these collections are uncataloged and often discoverable with the help of a finding aid.

Special collections in the art library can be delightfully peculiar or unusual. The Association of Independent Colleges of Art and Design (AICAD) ${ }^{1}$ is a consortium of 41 art colleges in the United States and Canada. Member institutions each have a library serving their student and faculty populations, while supporting the curriculum of each program. These member libraries provide some fascinating examples of the range and complexity that academic art libraries can embrace. Some college's library collections are wonderfully unique. California College of the Arts in San Francisco, for example, includes a seed library for plant fiber dyes to support their textiles program. The Maryland Institute College of Art hosts a penmanship collection, while the library at the Minneapolis College of Art and Design features picture files, LPs, record players and sunlamps as part of their unusual library menagerie. The Cleveland Institute of Art features a pop-up book collection. The University of Chicago acquired a video game collection. These are just some examples of distinctive resources provided by academic library collections.

The use of objects and "things" in the art library has been important historically and continues to grow. In fact, "materials libraries" support teaching and learning in programs of many kinds, from ceramics to industrial design. Companies such as Materials Connexion ${ }^{2}$, founded in 1997, provide an online database relating to materials, their use, and manufacture. They also offer physical subscriptions; sending participating libraries samples of materials and products that can support artists and designers who want to explore and interface with a material that may factor into a future project.

\section{DIGITIZED RESOURCES IN ACADEMIC ART LIBRARIES}

\footnotetext{
1 "The Association of Independent Colleges of Art and Design." AICAD, aicad.org/.

2 "Material ConneXion." Material ConneXion, www.materialconnexion.com/.
} 
In addition to traditional and non-traditional physical holdings, academic art library users generally can expect some form of electronic resources offerings in the form of full text databases, indexes, digital image resources, and in some cases, digital institutional repositories of student and faculty work.

Any discussion of the changing nature of library collections would be slightly askew if it ignored the increasing reliance of our patrons on digital content. While this is not uncommon across disciplines, art libraries have a unique relationship to these transitions. As outlined by D. Vanessa Kam in her 2014 article The Tenacious Book: the Curious State of Art and Architecture Libraries in a Digital Era, the art library collection has so far been slow to evolve. It still relies on print, as its material is slower to be available in digital format, often because image reproduction rights remain complicated, and the perception among scholars that analog resources are the gold standard.

Even though patrons may not be relying solely on digital resources, the digital era has arrived at the art library in many important ways. Institutional image repositories are an excellent example, and has turned librarians' image processing duties from slide production to metadata creation. This is a significant shift in the use of resources, certainly in format, but also in how space is utilized and how patrons are served. In short, the technology changes, and libraries rearrange their spaces and services to respond.

The understanding of patron needs and expectations becomes increasingly relevant as branch art libraries absorbed into the central collections on college campuses. This is addressed in a longitudinal study by Patton and Keogh in 2015 examining a rise in the closings of art and architectural branch libraries in ARL institutions. This shift indicates that the use of space in the art library as well as the use of space in the greater university context is also changing, as we see libraries of all kinds move towards fostering collaborative spaces and reducing the footprint of the stacks.

\section{MATERIALS IN THE ARTISTS' HANDS}

When envisioning future collections in the academic art library, it is essential to account for the population served by the library and listen to their voices. It is therefore logical to address the information seeking needs of visual artists and art students. Literature on this subject tends to support the anecdotal notions that art students are still heavily reliant upon print monographs, seem to enjoy browsing library stacks, and also utilize images and art objects as part of their research methodology. This is challenged, however, in a 2015 citation analysis of art students' thesis papers, as Katie Greer asserts that while print books are the principle resource in use, students are 
increasingly relying on internet sources. This move toward online resources makes a great deal of sense considering that using images in art related research and online databases such as ArtStor are essential as libraries move away from vertical picture files and slide collections. Web-based information retrieval is also indispensable when exploring very current events and work in the art world by necessity due to the information cycle. Reviews, exhibition announcements, not to mention the work of emerging artists and digital artists will be accessible sometimes solely online. More than ever before, materials that are of interest to art students are "born digital," which leads the art librarian to adapt service and access models, and consider different strategies for preservation.

In addition to format exploration in her citation analysis, Greer (2015) also explores the diversity in subject matter used in these citations by Library of Congress Classification. While material about the fine arts were well-used, materials from virtually all other disciplines were used as well, most especially Language and Literature, Philosophy, Psychology, Religion, and the Social Sciences. This supports Susie Cobbledick's observation in 1996, in her often-cited article The Information-Seeking Behavior of Artists, where she states that artists "make substantial use of libraries and print materials... much of that material is not art related...they typically find this material by browsing within specific subject areas" (343). These studies confirm that artists and art students make use of a wide variety of sources from all disciplines to explore their ideas. Using objects and images in research is also of great importance to the artist. Diedre Stam, in her 1984 study How Art Historians Look for Information, also asserted that information seeking in relation to art and art history relies directly to objects of art.

If art library collection development managers agree and respond to these assertions; the collection in the academic art library should ideally provide books on all subjects, access to an array of electronic resources, and should include images, artifacts, other materials, and archives. This is quite a large expectation.

\section{THE DISCUSSION COMES BACK TO...LIBRARY AS PLACE}

One seemingly enduring truth about libraries is the importance of how people interact with them as places. Do users find it welcoming and comfortable? Are they looking for solitude, collaboration, stimulation, or reflection? The sentiment of the 'library as place' is important to keep in mind as we look to the future of the academic art library.

Art and design students and professionals will be sensitive to the aesthetic qualities of a library space more than perhaps any other population. It is impossible to divorce the future of the collection from the future of the library space. What we collect and how our patrons use these resources inform the layout and successful utility of the 
library building. In Facilities Standards for Art Libraries and Visual Resources Collections from 1991 by Betty Jo Irvine, there are suggestions for how the library space can support aspects of our collections. The standards are instructive still today in how unique materials should be housed and preserved, such as environmental control for $35 \mathrm{~mm}$ slide collections, ephemeral material, photographs, and other media. It also suggests in standard 21 that "the art library shall provide a space for a microcomputer/typing rooms" (78), which seems antiquated now, but alludes to the fact that librarians have long understood that they must support the technological needs of their patrons, and provide space for the attending hardware.

\section{CASE STUDY: THE SMALL INDEPENDENT ART LIBRARY}

The library at the Oregon College of Art and Craft (OCAC), an independent art college with a student population of approximately 150 , is an example of a highly used and valued collection. The materials themselves are objectively well used and enhanced by the college's membership in its county public library system, affording its students access to a broader collection. The school is also a member of the Association of Independent Colleges of Art and Design (AICAD).

The collection is located on the ground floor of a repurposed residential house, and the faculty helped construct and paint shelving, ensured that there was adequate lighting, structural support, and other necessary amenities. The physical library space in this case is important to mention because it has a direct effect on the collection itself, as well as the use of the library by students, faculty, and community members. As is true with every library, shelf space did much to determine collection size, even when there was a needed expansion into a storage stack space. Print materials comprise the majority of the collection. Due to such a small student population, there is little need for concurrent users for reserve books, and with no online or distance learning courses offered, the college is somewhat of an anomaly compared to other schools who have genuinely compelling reasons to shift increasingly to electronic delivery of materials. Print material, especially pertaining to the study or art and art history is not inexpensive, but does not require dedicated staff time to upkeep various e-platforms, authentication, link resolvers, and various other endeavors that are required of a library that has committed to a more electronic model in their collection.

The library's usage statistics also suggested that the few electronic resources that were offered to students and staff were extremely under-utilized while circulation of print materials remained steady. This is the experience of one library, and could be due to a myriad of reasons, including inadequate promotion of the held electronic resources. Despite that possibility, there seemed to be a genuine, deeply held feeling among both students and faculty that print was preference. This is a collection supporting an art and 
craft college, so its population self-selects as a group that engages with haptic practice; enjoys using their hands.

Still, one should be unsatisfied with this rather anecdotal orientation to student habits and preferences, so more direct study and outreach was performed. A Student Library Advisory Committee was created by the librarian, which was meant to be a direct conduit for student input into the library's collection and services. This was a counterpart to the Library Committee, which was run by the faculty and included a rotating membership of no less than three faculty members, the librarian, and the academic dean serving as an ex-officio. The Student Library Advisory Committee was less formal. The Student Commonwealth, the college's version of a Student Body Council, was approached and asked for volunteers who would attend a lunch session at minimum once per semester, and report back and forth at the Student Commonwealth meetings. As an incentive to volunteer, lunch was provided by the librarian.

The committee solicited student feedback about how the library collections were supporting their studies, what services and resources they used, and what they would like to see change. These sessions were reasonably well attended by the college's standards, in that 6 or 7 students engaged in the session. While this does not appear to be a large turnout, it does constitute $4-5 \%$ of the student body.

Of the discussions that transpired, the principle takeaway was that the students were largely satisfied with the print collection, which was by far the preferred format. It was of little surprise that many of the students were not heavy users of the databases provided by the library unless compelled to do so by their instructors for a specific assignment. This matched up with the dismal usage stats of library electronic sources. There was dissatisfaction regarding limited open hours and limited study space, which was anticipated feedback. The students were able to understand the budget constraints the library was operating under, which explained the hours and space limitations. Above all, it seemed most important that the students felt heard and involved in the running and basic makeup of the library and its services. These students reported back to the Student Commonwealth, so this information was disseminated to the larger student body, and the meeting was reported upon to the faculty Library Committee.

In addition to the Student Library Advisory Committee, the entire college community was given a survey every three years to determine general satisfaction and solicit suggestions about the library and its services. In an environment that experiences a great deal of survey fatigue, especially toward the end of the school year, each survey had a very high response rate. The survey questions targeted satisfaction with service, including timeliness of request fulfillment, and professionalism of staff. Other questions 
dealt with perception of the library's space physically and virtually. It did not engage the community in a full user experience evaluation of the website, but it did ask some general questions about whether they used the site, how easy was to locate what they wanted, and so on. Finally, the questions tried to assess respondents' feelings about the collection in terms of its scope, depth, and quality.

The student focus group and the survey results provided great insight into the habits and preferences of the population served by the library. It reinforced that the collection was appreciated and that library services were on the right track. There were content suggestions, such as expanding graphic novel holdings, but by and large, the feedback was supportive of the collection. Students recognized the space constraints the library experienced, and in terms of holdings were not as attached to certain materials as some faculty. More specifically, the back issues of bound periodicals which grace the reference room were seen, probably rightly so, as needless space-wasters that should be moved out to storage to make way for a zine-swap space. One considerable change to the collection involved heavy weeding of the reference section to make way for the beginnings of a materials library. A new faculty member was instrumental in that launch, and had begun gathering materials for this small collection with some unusual pieces that the students could interact with, such as objects from the 3D printer, material swatches, sustainably farmed wood samples, and so on.

Another positive step forward that came from the Student Library Advisory Committee was to address the underutilization of the institutions' undergraduate and graduate thesis papers. They were present in the library catalog, but not discoverable to students in a way they liked. The papers were cataloged each year, and the digitized images of the work was put on the school's digital image database with attending metadata, yet the students reported only using the papers when their thesis advisors made specific recommendations for them to go find one by name. This was not ideal, and therefore a plan was devised to create a dedicated online environment to the work that was searchable by graduation year, subject headings, and tags.

The greatest outcome of the experience for the students was the sense of ownership of the library that resulted in these participatory exercises. Once these activities were launched, there was more conversation about new things the library could be doing on campus in the future.

\section{CONCLUDING THOUGHTS}

The experience of one librarian at a small independent art college library can inform how library professionals address the future of library collections. While this is a very specific case, realities of all institutions are in play: the limitations of budget and space, 
access to the collections (whether because of open hours or format delivery), and the buy-in from the library's community. OCAC's cross-institutional relations are also indicative of a wider trend, in which libraries embrace more consortial collection development and even communal storage.

The academic art library collection of the future will continue to transform, of that there is no doubt. One important constant, however, will remain: it will support an inventive and original community, and be located in a place of critical thinking and creative action. In terms of collection makeup, there is compelling evidence that students and faculty will continue to benefit from a robust print collection. This is due to the patrons' preference and to the scarcity of usable electronic resources and license considerations for their material. As time marches forward, however, librarians should expect some of these barriers to change, resulting in a continued shift towards preferring electronic resources. This is especially true for makers of "born-digital" art, and creative software designers. The proliferation of digital image repositories, and the growth of existing visual resource consortia, suggests that digitization initiatives will continue to be favored above the image services of bygone days of the vertical image files and slide libraries. While certain elements of an art student's research will continue to move online, much of the collection will still be composed of objects that can be touched, interacted with, and held. This is particularly evident in materials libraries.

It is unwise to prescribe an exact vision for the future academic art library, as there will not be a single template for each institution, but perhaps it will be useful to consider the following:

- There will be challenges associated with budgets and space

- Resources will be stretched to be allocated for competing priorities

- Technological needs will continue to instruct the use of library space and budget

- The library will be responsive to the needs and desires of the community it serves

- The library will be committed to student-centered design

- The patrons will feel ownership of the space and resources

- Collections will include regionally and curriculum-relevant materials

As long as art library collections respond to their community's needs and receive sound stewardship, they will undoubtedly hold a valued place in the academy.

Prescribing a roadmap for the future academic art library is difficult long-term because the future is not a destination. What a "normal" collection will look like in twenty-five or one hundred years will not be a finished product, but simply another iteration of its growth. The most actionable step a library can take to plan for their futures is to 
integrate outreach and feedback solicitation into their strategic plan. Listening to students' voices will inevitably keep library collections current and forward-facing. 


\section{REFERENCES}

"The Association of Independent Colleges of Art and Design." AICAD, www.aicad.org/.

Cobbledick, Susie. 1996. "The Information-Seeking Behavior of Artists:

Exploratory Interviews." The Library Quarterly: Information, Community, Policy, 66(4): 343-372. https://www.jstor.org/stable/4309154

Greer, Katie. 2015. "Connecting Inspiration with Information: Studio Art Students and Information Literacy Instruction." Communications in Information Literacy, 9(1): 8394.

http://www.comminfolit.org/index.php?journal=cil\&page=article\&op=view\&path\%5B\%5D $=\mathrm{v} 9 \mathrm{i} 1 \mathrm{p} 83 \&$ path $\% 5 \mathrm{~B} \% 5 \mathrm{D}=208$

Irvine, Betty. J. 1991. Facilities Standards for Art Libraries and Visual Resources Collections. Englewood, CO: Libraries Unlimited, Inc.

Kam, Vanessa. 2014. "The Tenacious Book, Part 1: The Curious State of Art and Architecture Library Collections in a Digital Era." Art Documentation: Bulletin of the Art Libraries Society of North America, 33(1): 2-17. http://search.ebscohost.com/login.aspx?direct=true \&db=Ilf\&AN=95527258\&site=ehostlive

"Material ConneXion." Material ConneXion, www.materialconnexion.com/.

Patton, Stephen and Keogh, Kristina. 2015. "The Branch Art Library in ARL Institutions: A Longitudinal Study and Environmental Scan." Art Documentation: Bulletin of the Art Libraries Society of North America, 34(2): 249-266.

http://search.ebscohost.com/login.aspx?direct=true\&db=If\&AN=111312517\&site=ehostlive

Stam, Diedre.1984. "How Art Historians Look for Information." Art Documentation: Journal of the Art Libraries Society of North America,3(4): 117-119.

\section{Further Reading}

Albrecht, Kathe. 2009. "The Visual Resources Center in the 21st Century." Visual Resources Association Bulletin, 36(3): 47-56.

http://search.ebscohost.com/login.aspx?direct=true \&db=Ilf\&AN=502989219\&site=ehostlive

Carter, Sarah. 2016. "Aligning Circulation Policies with Student Needs and Collection Value: A Historic Comparison of Trends in Academic Art Libraries." Art Documentation: Journal of the Art Libraries Society of North America, 35(2): 262-280. doi: $10.1086 / 688727$ 
Hemmig, William. 2009. An Empirical Study of the Information-seeking Behavior of Practicing Visual Artists. Journal of Documentation; Bradford, 65(4), 682-703. Doi: 10.1108/00220410910970302

Jagoda, Patrick. (2012). Videogame Collection Supports Scholarly Study. The University of Chicago Library News.

http://news.lib.uchicago.edu/blog/2012/05/25/videogame-collection-supports-scholarlystudy/

Krivickas, Jennifer and Meyer, Elizabeith. 2012. "Future or Fate: The Slide Collection of the Robert A. Deshon and Karl J. Schlachter Library." Visual Resources Association Bulletin, 39(3): 1-4.

http://search.ebscohost.com/login.aspx?direct=true \&db=\|lf\&AN=86972607\&site=ehost$\underline{\text { live }}$

Kusnerz, Peggy, ed. 1989. The Architecture Library of the Future: Complexity and Contradiction. Ann Arbor, MI: The University of Michigan Press.

Macken, Megan. 2006. "The Art Library as Place: The Role of Current Space Planning Paradigms Within the Academic Art and Architecture Library." Art Documentation: Bulletin of the Art Libraries Society of North America, 25(2): 18-25. http://search.ebscohost.com/login.aspx?direct=true\&db=\|lf\&AN=502893766\&site=ehostlive 